\title{
Women, the Informal Economy and the State in Lesotho
}

\author{
Mark Chingono ${ }^{1 *}$ \\ ${ }^{1}$ University of Swaziland, Kwaluseni, Swaziland \\ *Mark Chingono, E-mail: markchingoni@yahoo.com
}

Received: June 22, 2016

Accepted: July 20, 2016

Online Published: November 28, 2016

doi:10.22158/wjssr.v3n4p629

URL: http://dx.doi.org/10.22158/wjssr.v3n4p629

This paper is part of a broader study in progress about the political economy of gender transformation in Lesotho. The study was made possible by a research grant from the Organization for Social Science Research in East and Southern Africa (OSSREA), to which the author is grateful. The findings and conclusions of the study are those of the author, and do not necessarily reflect the views of OSSREA.

\begin{abstract}
Poor women in Lesotho endure a triple jeopardy of exploitation by patriarchy, capitalism and the state. To escape from this jeopardy increasing numbers of poor women are entering the informal economy, which is increasingly becoming the major dynamic and expanding sector of the economy. Becoming informal entrepreneurs has not only financially empowered women, but has also subverted traditional patriarchal gender power relations. This paper, based on a critical field survey, considers the experience of women in the informal sector, changes in gender and class relations and the contribution of the informal economy to national development. The paper shows that the informal economy is a contested terrain in which kinship values of the economy of affection coexist in dynamic tension with those of primitive capitalism, and that the patriarchal and weak state is the major obstacle to poor women's emancipation. It concludes that, since the informal economy is the only vehicle for poor women's empowerment, policy must optimize the benefits of the informal sector while limiting its excesses.
\end{abstract}

\section{Keywords}

development, emancipation, empowerment, enterprising, formal sector, gender inequality, informal economy, patriarchy, policy, women, state, traders

\section{Introduction}

Lesotho, an enclave economy completely surrounded by South Africa (SA), is grappling with an economic crisis of considerable proportions. The crisis is characterized by rising unemployment, poverty, crime, disease, violence and political instability. Since 1987 nearly 60 per cent of the population has lived below the national poverty datum line, and "there has been a persistent fall in household income as indicated by GNP per capita" (Mapetla \& Petlane, 2007, p. 73). The 1980-1990s 
International Monetary Fund (IMF) economic reforms, the retrenchments, the privatization programme, the streamlining of bureaucracy divesture (Makoa, 1996) and drought and floods have compounded the situation. The country's heavy dependency on SA and foreign aid has limited its capacity and policy options for addressing the mounting crisis. In response to the continuing crisis, increasing numbers of poor women are taking the initiative to solve their economic problems by engaging in informal entrepreneurship. Today, and as in most developing countries, women constitute a majority in the informal sector and the majority of economically active women are in this sector (Women in the Informal Economy Global Organization, WIEGO, 2003). Located within the dynamic interaction of global economic processes and local development politics, the informal sector is a hybrid arrangement which is numerically dominated by women, and in which trade rather than production is the main economic activity.

The resurgence of a women majority informal economy raises fundamental questions: Which of the many feminist and development theories best capture the essence of the processes unfolding in Lesotho's "feminine" informal sector? Does the informal sector contribute to national growth and development, and if yes to what extent? What is the relationship of the formal sector to the formal economy and the state? Finally, what kind of policies will best promote women's emancipation as well as give a positive form to the informal sector? These are difficult questions, and only tentative answers are attempted here, if only to invite further debate.

Qualitative in orientation, this paper is based on a critical field survey and secondary literature, which reveal subtle connections and processes that point to a restructuring of the politics of gender and development and the emergence of new gender and class relations. Specifically, the paper argues that, because of its easy entry requirements, the informal economy is the only route by which poor women can escape from patriarchal control and poverty. In addition to improving the human security of women informal traders and their families, the informal sector has also given women an economic base for supporting their struggle for gender equality and political visibility. Translated into political power, women's financial independence has led to a fundamental reconfiguration of gender power relations. Yet, the informal economy has also reproduced some of the worst excesses of capitalism and patriarchy. The paper concludes that, women informal traders are important agents of change and development, and therefore public policy should be re-oriented to assist them and give a positive form to their efforts.

\section{Background and Context}

Notwithstanding official policy pronouncements to promote gender equality, women continue to endure gender inequality and discrimination in Lesotho. Mapetla and Petlane (2007, pp. 30-31) observe, "unequal gender relations" remain "a common feature of Lesotho society, in both the private and public spheres". Women remain a subordinate "second sex", conspicuous by their absence in positions of power and influence. The predominantly male ruling elite have used state power largely to protect its 
narrow political and economic interest. To fight against this political and economic marginalisation women have turned to the informal economy. But, because "Lesotho does not have an informal sector policy despite rapid growth of the sector in the past two decades" (Mapetla \& Petlane, 2007, p. 78) the full potential of women informal entrepreneurs remains unrealized. As in much of Africa, the state in Lesotho is unable to adequately advance the human security, welfare and rights of women and to provide them with adequate employment, education and health. With only water as the "most significant natural resource", which is exported to SA, the Basotho state is a weak state with limited resources and options.

\subsection{The State in Lesotho}

The state in Lesotho is not only fragile, but is also at the centre of the crisis of underdevelopment, poverty and political instability. As Ferguson (1990)'s The Anti-politics Machine suggests, the development apparatus and institutions in Lesotho may have generated negative and even unintended effects-depoliticization and increase in bureaucratic power. Indeed, since independence in 1966 there has been a vicious Machiavellian struggle among the elite to capture, control and consolidate state power and use it to subdue opponents. Mapetla and Petlane (2007, p. 13) aptly put it:

This dynamic has included three coup d'etats (in 1970, 1986, and 1994) and twenty three years of undemocratic government, including seven years of military rule. The last ten years of democratic restoration (1993-2003) have seen the establishment of a virtual one-party state.

The most recent coup attempt was in 2014 , and it was the intervention of the Southern Africa Development Community (SADC) that averted the deterioration of politics into violence.

With political "instability, controversy and conflict" becoming the main defining features of Lesotho's post-independence political landscape (Mapetla \& Petlane, 2007) issues of gender equality and the informal economy are hardly prioritized in policy formulation. Although weak in relation to other states and some international actors, the Basotho state is relatively powerful in relation to the weaker "second sex" and the weaker "second economy", and has indeed, through policy omissions and/commissions, influenced their fate. For such a weak and unstable state prioritizing gender equality and the informal sector may seem a luxury but, as argued herein, gender equality and informal enterprising bolsters state security.

\subsection{Women in the Literature}

de Beauvoir (1964), the mother of modern feminism, made important distinctions between sex and gender. She conceptualized women as "the other, second sex", declared that one is not born, but rather becomes a woman, and that biology is not destiny (de Beauvoir, 1964). Her followers have splintered into different ideological schools, with conservative, liberal, Marxist/socialist, radical, environmental (ecofeminism) post-colonial, post-modern and cultural feminism vying for influence (Oyewumi, 2015; Buttler, 2006; Ford, 2002; and Sow, 1997). None of these contending perspectives is entirely correct or wrong. Instead, they each give a partial picture of the far more complex reality of feminism and gender 
politics. The reality is, feminism has become a kaleidoscope of "many-faceted responses of a multitude of women wrestling with the question of self-determination, seeking social changes that will give them greater justice, power and dignity" (Keen, 1996, p. 195). Class, race, religion, ethnicity all combine in defining the forms which women's struggle for gender equality take. Such complex and multi-layered struggles by women for emancipation are not amenable to mono-casual analysis. Accordingly, this paper is based on acritical synthesis ofdifferent and contendingfeminist perspectives.

\subsection{Gender Relations in Lesotho}

During the pre-colonial era, patriarchal traditions, idioms and ideologies restricted women's participation in the public sphere, and instead forced them to remain invisible "workhorses" of the household (Gill, 1997; Mueller \& Martha, 1977). Leadership and entrepreneurship were qualities associated with masculinity, and only male children were nurtured to acquire and develop them, for they were expected to be household heads and breadwinners (Machobane, 1996; and Murray, 1997). Rooted in political economy, the subjection of women was buttressed by patriarchal and religious ideologies and traditional institutions which define and/or limit the rights, options and possibilities available to women. The traditional unequal power relationship between the sexes was redefined, with ambiguous implications, during colonialism.

On the one hand British colonial rule, by guaranteeing the protection for the Paramount Chief, left gendered Basotho customs and institutions relatively intact, and today some ancient traditions still persist. On the other hand, and especially through Christianity, which today accounts for an overwhelming 80 per cent of Basotho people as compared to only 20 per cent who adhere to traditional beliefs (CIA, 2002), some changes in matrimonial law and gender relations were introduced. For example, Christianity freed women from certain archaic and abusive traditional practices, such as genital mutilation, polygamy, forced marriages and total subservience to male relatives. Christianity, however, also entrenched certain aspects of gender domination and female subservience to males. For example, by elevating the husband to the unquestionable household head it further disempowered women. Similarly, by eroding the support mechanisms of the traditional extended family, kinship ties, and the "economy of affection", colonialism exposed women to greater vulnerabilities and insecurities, and to "Western forms of sexism, which are often more oppressive to women than previously existing social relations" (Sacks, 1982, p. 1). In fact, as in the pre-colonial era, the sex division of labour at the economic level and the ideology of patriarchy at the political level continued to limit women's access to power.

Independence was attained in 1966, but it has not brought about fundamental changes in gender relations. Patriarchal in orientation, the state has pursued gender discriminatory employment practices which have resulted in massive under-representation of women in both the private and public sectors. For example, of the estimated 25 per cent to 35 per cent unemployment, 66.5 per cent are women (Mapetla \& Petlane, 2007, p. 29). With such high levels of unemployment among women, and with 100 
females for every 97.8 males in the population (Bureau of Statistics, 2003), the situation of poor women in Lesotho is dire. As in Swaziland, women continue to experience "unequal treatment in the political, economic, social, legal and cultural spheres because of systematic gender discrimination" (Nyawo \& Nsibande, 2014, p. 47). The government seems ill-equipped to eradicate poverty, let alone deliver on its development plans to redress gender injustice, as promised, for example, in the Kingdom of Lesotho, Third Five-Year Development Plan, 1980-1985. With their needs fading into policy insignificance, poor women were forced to join en masse the informal sector.

\subsection{The Informal Economy}

Since Hart (1971) coined the term "informal economy", the status of this economy, its scope, features, contribution to development, relation to the formal economy and to the state, have been hotly contested issues. On the one hand, the informal economy is depicted as "the other path" which offers the "promise of new income generating activities which would help the poor, 'without any major threat' to the rich" (Worsely, 1984, p. 210). From this optimistic perspective, the informal economy is supposed to further development because it is less capital intensive and less dependent on foreign exchange and technology than the formal economy; it's supposed relative autonomy gives it further potential for expansion (MacGaffey, 1991).

On the other hand, the informal economy is denigrated as unhealthy, exploitative, repressive, bordering on illegality, and as habouring criminals. Portes and Walton (1981) criticize the informal for exploitative and of subsidizing big capitalists of the mainstream economy; as a source of cheap goods and services for their labour force it allows them to pay extremely low wages. Others condemn it as a "sinkhole of exploitation" (Preston-Whyte \& Rogerson, 1991) that perpetuates underdevelopment. Yet others still, like Broomley (1992), advance methodological objections: Why assume there are only two sectors? Are the formal and informal sectors really independent of each other? The reality is, whether its effects are good or bad, the informal economy, known variously as "underground", "parallel", "unrecorded", "second", "hidden", "shadow", “endogenous", "irregular", "alternative”, "unofficial” or "black economy" exists alongside official economic activities in most countries in the world (Keith, 1971; MacGaffey et al., 1991; Preston-Whyte \& Rogerson, 1991).

Maseru's informal economy is indeed flourishing and expanding rapidly, and it exhibits a more complex picture which defies rigid analytical categories. A closer look suggests that, in spite of its negative image and effects, the informal sector has immensely enhanced the human security of the traders, contributed to narrowing gender inequalities, and stimulated economic growth and development. The relation of the informal economy to the formal economy, and to the state, is complex, and is sometimes cooperative and other times confrontational.

\subsection{The Emergence, Expansion and Impact of the Informal Economy}

Today the informal sector is the fastest growing sector of Lesotho's economy. Its history dates back to the pre-colonial era where "the economy of affection" (Note 1) and kinship ties were central to 
economic organization and production. Since formal economic systems and institutions are still embryonic in much of rural Africa, this informal mode of economic production and organization is being reproduced - especially by those emigrating from rural to urban areas, and who cannot find jobs - in urban areas at an alarming rate. Thus, unemployment and poverty have been the midwife for the emergence of this specific kind of capitalism. Dispossessed and disempowered through the dominant development models, poor women — and men—have flocked to the informal economy. The informal economy is attractive primarily because of its easy entry requirements. Although decisive of one's chances of success and prosperity, capital, qualifications or experience are not required: the downside is, no protection is offered in the informal economy.

\subsection{Women in the Informal Economy of Lesotho}

The Maseru City Council (MCC)'s register of informal traders reveals that by the end of 2003 a total of 2744 informal traders were operating legally in the city. These registered informal traders paid a fixed monthly fee to the city council, which varied according to the location of the market, security and facilities provided by MCC (MCC, 2003). The register further reveals that about 70 per cent of registered informal traders are women and only 30 per cent men. An official of the MCC explained it thus: "Men don't register" (MCC, 2003). Although some men informal traders do not register, it is clear from the survey that 65 per cent of informal traders are women. Why are women a weak majority in Lesotho's informal sector?

The numerical domination of the informal economy by women can be traced back to the discovery of gold in the Transvaal in the 1870s when Basotho men started seeking employment in South African mines, leaving their wives behind in the rural areas to endure rural poverty and economic insecurity. Rural poverty forced some of the women to migrate to urban areas where they engaged in informal economic activities. According to the Bureau of Statistics (2003, p. 51), past influences of fertility, mortality and migration have also contributed to this gender bias in the informal sector. For every 100 females there are 97.8 males in the age groups of 5-34 years in urban areas, and this could be due to higher male mortality and emigration as well as of net female migration from rural to urban areas (Bureau of Statistics, 2003).

In addition to past influences and migrations, the gender discriminatory policies and practices of both the public and private sectors have further contributed to forcing women into the informal sector. For example, while in the economically active group there are more females than males in the urban centres (Bureau of Statistics, 2003), the sexist ideology of the state encourages the employment of males in both the public and private sectors. As the Bureau of Statistics (2003) point out, although "literacy levels, school attendance, and level of education completed are higher for females than for males ... labour force participation rates, at one in two males and one in four females, were much lower for females than for males". Similarly, long-term unemployment is higher for females than for males and higher at older ages than at younger ones; after the ages 50 years unemployed females are unlikely to 
ever obtain employment (Bureau of Statistics, 2003). Consequently, females are about three times as likely as males to be economically dependent, just as males are twice as likely as females to be heads of households (Bureau of Statistics, 2003). As more women join the informal economy and become economically independent, these figures are slowly changing.

\subsection{Who are the Informal Traders?}

The opportunity structure provided by the urban economy conditioned the processes of informal entrepreneurship. Housewives, single mothers, widowers, pensioners, and unemployed youth constitute the majority of informal traders. Retrenched male workers have also sought refuge in this sector. Although some criminal and illegal activities do occur in the informal economy, the majority of female informal trades are innocent citizens trying to eke out a living. Most informal traders come from the lower social classes. Some are happy working in the informal sector while others dislike their work, 56 and 44 per cent respectively according to Shea (2003). The majority of women traders are sole owners of their businesses. According to Kotelo (2003), about 70 per cent of female informal traders are sole breadwinners, while the remaining 30 per cent are either supplementing their family's incomes. Below is a schematic discussion of the demographic attributes of a sample of 100 female informal traders of Maseru city.

\subsubsection{Age}

Table 1. Age of Informal Traders

\begin{tabular}{ll}
\hline Age & Percentage \\
\hline $10-19$ & 4 \\
$20-29$ & 49 \\
$30-39$ & 23 \\
$40-49$ & 16 \\
50 and above & 8 \\
\hline
\end{tabular}

As Table 1 above indicates, 49 per cent of informal traders are within their twenties. This suggests that youth and recent school leavers are failing to get formal employment. Given the universal early marriage in Lesotho, in which 48 and 47 per cent of males and females, respectively, aged 15 years and over are married (Bureau of Statistics, 2001), this age group is comprised of young parents who have young dependent children, and who therefore have more pressing financial needs.

\subsubsection{Education}

Table 2. Education of Informal Traders

\begin{tabular}{ll}
\hline Education & Percentage \\
\hline None & 6 \\
\hline
\end{tabular}




\begin{tabular}{ll}
\hline Primary & 58 \\
Junior Secondary & 26 \\
High School & 10 \\
Total & 100 \\
\hline
\end{tabular}

At 58 per cent, the majority of women informal traders have only attained primary education. Yet, education is the major determinant of the type of informal enterprise that one engages in, and hence the incomes earned and chances of success. Women with high school education tend to engage in more sophisticated businesses, such as, confectionery, which are more financially rewarding, while the uneducated mostly engage in less rewarding businesses such as, selling vegetables.

\subsubsection{Marital Status}

Table 3. Marital Status of Informal Traders

\begin{tabular}{ll}
\hline Marital Status & Percentage \\
\hline Single & 34 \\
Married & 55 \\
Widowed & 7 \\
Divorced & 2 \\
Separated & 2 \\
Total & 100 \\
\hline
\end{tabular}

At 55 per cent, and as in Mafeteng (Kotelo, 2003), the majority of informal traders in Maseru are married women. Why? First, having been retrenched, their husbands can no longer adequately provide for their families. Second, some women need to supplement their husbands' poor wages. Third, others have absentee and irresponsible husbands who spend all their earnings on beer and other women. Finally, the patriarchal control of resources within the household force some women to find ways of income generating to cater for things—-such as hairdressing and manicure—not deemed essential by their husbands.

\subsection{Motives for Informal Trading}

The immediate motives for starting informal business ranged from the need for basic survival, supplementing income to making profit and generating wealth. The overwhelming majority of respondents cited poverty and failure to get decent formal jobs as the reason for starting informal trading. When the motive is survival, the entrepreneurs tend to be content with just enough income to survive, and often when the target is met business closes. If profit is the motive, often the working hours are longer, and the potential for growth greater. 


\subsection{Sources of Capital}

Dispossessed and without capital, the majority of informal traders are not eligible for bank loans as they have no collateral. Demonstrating the resilience of kinship ties and the economy of affection, 44 per cent of the respondents got initial capital from relatives and another 10 per cent from friends and lovers. Out of the 44 per cent, and as evidence of the gender-based economic imbalances, 18 per cent were wives who got money from their husbands. A significant proportion of women had used savings from the poorly paying Chinese garment factories (Baylis \& Wright, 1993). In a nutshell, different women in the informal sector got initial capital to start off with from different sources, and these reflected their social status, personal histories and networks.

\subsection{Sources of Goods: The Formal/Informal Divide - A False Dichotomy?}

Virtually all the goods traded in the informal sector are obtained from the formal economy, either from wholesalers in Maseru city or SA. To this extent the informal sector provides a ready market for the formal sector. Second, some goods being sold on the formal market are acquired from the informal economy, for example, beef from cattle rustling and smuggled electronic gadgets. Third, most of the customers of informal traders are poorly paid formal sector workers, and in fact the informal sector is indirectly subsidizing the formal sector. Clearly, the informal economy and the formal economy mutually feed on each other, and the dichotomy between them should not be exaggerated.

\section{Challenges of Informal Trading}

Informal traders face a host of challenges that adversely affect their operations. These challenges include, stiff competition and low incomes, harassment by the MCC police, the perishability of goods, the failure by debtors to repay, and rising transport costs. Stiff competition within the informal sector, and with formal business, is considered the most serious challenge. Contrary to classical economic theory, which posits that competition leads to efficiency and better quality goods and services, in the informal economy competition leads to many other things such as: unviable under-pricing; negotiating and reducing prices on the spot; sweet-talking customers; conflict among traders; the use of magic and witchcraft; moving from place to place; barter trading; selling goods in the smallest possible quantities; working for longer hours; and selling to people who come from the same village. Clearly, some of the strategies, such as working late, are not only too dangerous for women, but also impractical for women as they need to go home early to attend to household chores. In short, fierce competition means that "business ceases to be profitable" and incomes fall.

The second major problem is low and falling incomes, which is a result of competition and falling disposal incomes in the formal sector. The incomes earned per day vary considerably from nothing to over US\$60, and this depends primarily on the type of goods being traded. Goods with high value added could fetch as much as, or even more than, middle income earners in the civil service. While clothes fetch more money, sales from clothing per day are usually low as many people buy clothes at 
month ends, and often in bigger shops. Food, fruit and vegetables, unlike clothes, are bought on a daily basis, but for much lower prices. Partly due to the traditional gender division of labour, and partly due to their lack of skills and previous experience, most women sell raw goods, such as food and vegetables, which fetch small or no profits.

The third challenge facing informal traders is harassment by municipal police. According to one informal trader:

The MCC police is our major threat, because it wants us to move from this place. But we do not know where to go, for the market place (built by the government) is full.

Another street vendor commented thus:

The government and the MCC are removing us from the streets because they do not want the visiting SADC heads of states and governments to see the abject poverty we are experiencing in this country (Thakalekoala, 2003, p. 2).

Whenever the MCC police raid the vendors, the confiscated items are rarely returned, often leading to a total collapse of business.

On its part the MCC (2003) accuses informal traders of not cooperating with the government:

If informal traders cooperate with the council Lesotho would, like Botswana, develop rapidly. But unfortunately, the informal traders of Maseru like spending their time striking and rioting.

Such clashes and counter-accusations are counter-productive. Efforts should instead be directed towards building mutual trust and a new economic contract between the state and informal traders. In addition to the police harassment, fellow traders fight, steal or destroy rivals' goods (Kotelo, 2003).

The fourth most common problem is the perishability of goods, such as, vegetables and food, which result in heavy losses. Most informal traders sell the same type of goods, especially vegetables, and the glut in the market means that some of these goods deteriorate in quality before being sold. When that happens, informal traders undersell their products or simply throw them away, either way incurring losses. Since the provision of cold rooms seems a remote possibility, perhaps traders should aim at diversification into inexpensive non-perishable goods.

The fifth problem, which is a constant threat, and which can lead into bankruptcy, is defaulting clients and debtors. Business and contract law are all meant to deal with such problems, but applying these laws in the informal economy is almost impractical, for contract documents and transaction receipts are usually non-existent. In demanding payment, some men informal traders resort to using physical force, an option not available to most women traders. In short, informal traders face numerous challenges, and they have turned to the government for assistance.

\subsection{Informal Traders' Demands}

Informal traders have made numerous demands to the government. In order of priority, these include: business loans; safe markets; jobs creation; study and training scholarships; mediation between MCC and informal traders; subsidies for informal traders; and a ban on supermarkets from selling certain 
goods. Informal traders want business loans because lack of capital is the major obstacle facing these aspiring "capitalists without capital". Without capital these barefooted capitalists will not be able to graduate into fully fledged entrepreneurs. Remedial policy should therefore aim at providing credit facilities to women informal traders.

Safe and sheltered markets were needed, for poor shelter attracted thieves, and in rainy weather goods were damaged and business disrupted. The sheltered market built by the city council for informal traders in the city periphery was always empty. Informal traders were reluctant to use it because it was located "too far away from customers", and hence not good for business. While building a market for informal traders was a noble idea, democratic consultation between the MCC and informal traders was necessary to ensure that the practical needs of both parties were met.

The calls for the creation of more formal jobs suggest that some informal traders were in the sector as a temporary stop-gap measure, hoping to get a formal job at some point in the future; this attitude partly explains the less than optimum operation of the sector. The creation of more formal jobs would decongest the informal sector, reduce competition and therefore ensure reasonable returns. But Lesotho is flying in the opposite direction as the reforms, retrenchments, privatization, bureaucratic streamlining and political instability are creating more unemployment. Thus unless there is a change of direction, the quest for more jobs will always remain a far cry from this unforgiving reality.

Informal traders wanted study and training scholarships because poor education and the lack of necessary business skills limited their developmental potential. In the contemporary informational era, application of knowledge - based information is an indispensable ingredient of success in any business venture. In order to prepare good plans, invest wisely and grow rich, informal traders need to apply knowledge-based business systems, which they can only acquire through further education and training.

Informal traders also demanded that government intervene to end confrontation between the MCC police and informal traders, which cause destruction of property and injuries to people. The regular running battles between informal traders and the MCC police demonstrate that the reciprocal expectations of informal traders, as citizens, and the state are frustrated. Policy should therefore aim at harmonizing the needs of informal traders and the interests of the state.

Some informal traders felt the government should subsidize them in order to enable them to sell their goods at prices affordable to the poorest. Nothing demonstrates the extent to which the reciprocal expectations of informal traders and the state are at odds than this naïve hope: Instead of subsidizing informal traders the state wants to tax them and suppress their activities.

The demand expressed by a small minority that government should ban supermarkets from selling certain goods sold by informal traders is not only unacceptable in free market economy like Lesotho, but also reflects the extent to which informal traders have rather misplaced faith in the government, which panders to big capital. Perhaps informal traders should specialize in areas where they have a 
comparative advantage. In short, although some demands of informal traders are unrealistic, others could be addressed through policy that builds on the synergies between the formal and informal economy and that promotes gender equality.

\subsection{The Informal Economy and Gender Transformation}

Epprecht (2000) in a title of his book on Lesotho asks: Is This Matter of Women Getting Bad? The dynamics of the informal economy have made this matter even more complex and ambiguous. On the one hand, with more and more women informal traders enjoying enhanced human security, increased financial independence, and more political power, things seem to be getting better. Yet, on the other hand, things are getting worse, as patriarchal stereotypes and the worst excesses of capitalism are reproduced in the informal economy.

The "matter" seems to be getting better for a number of reasons. First, the fact that a significant proportion of women are now active in the informal economy is a revolution in itself, for in the past women were looked after by their male relatives. Second, and related, incomes from the informal sector have improved the human security and welfare of traders and their families. Women in the informal sector are using their income to buy food and clothes, pay rent, school fees, tuition and pay for leisure. Remarkably, some are even managing to send their children to university. Were it not for incomes from the informal sector many more would be hungry, poorer and destitute or even criminals or sex workers. Third, increased access to income has reduced women informal traders' risks of dependency on men, and has given them some financial autonomy. As Ntabeni-Bhebe (2011), an enterprising woman, asserts, financial independence is what every woman needs. Not dependent on men for their basic needs, some women informal traders are now more in control of their lives and incomes.

Forth, access to income has helped women increase their decision making powers within their households, and to reverse some traditional gender roles. Remarkably, and suggesting a reconfiguration of power between the sexes, an overwhelming 88 per cent of women informal traders said they decide for themselves what to do with their incomes; only 10 per cent decide together with their partners. Some women have become household heads. This is a radical departure from traditional patriarchal practices, which made it men's prerogative to make decisions on such important household matters. In a related radical gender role reversal, about 6 per cent of women informal traders claimed to be supporting their husbands with their incomes. In yet other cases of gender role reversal, successful women informal traders employed men as body guards and chauffers.

Fourth, women's new economic opportunities have helped them forge new social identities which centre around work, fashion and leisure, and which are based on class and western cultures. Reflecting the new autonomous identities, young women spend a significant proportion of their incomes on cosmetics, fashionable clothes and pleasure.

In short, as women responded to their situation not as passive victims but as active agents of change, there has been a remarkable improvement in their position vis-à-vis men. In particular, the informal 
economy has helped liberalize gender relations by forcing men, formerly the sole breadwinners and household heads, to let go and allow women to be bread winners and house-hold heads too. Emboldened by their new incomes, women are becoming more assertive in demanding equal rights and in redefining their identity. Such radical changes which empower women and enhance gender equality constitute a "quiet gender revolution". Yet, at the same time, especially through the acceleration of social differentiation, divisions among women, and the reproduction of some traditional gender stereotypes, women are being disempowered.

\section{Social Differentiation and Division}

The informal economy, while offering promises of emancipation for women, has also disempowered them by accelerating social differentiation and divisions among women. With some women bringing in skills and savings from previous jobs, and others bringing nothing, the informal economy is both a site for accumulation of wealth and pauperization, social differentiation and class formation. Wealth acquired through the informal economy has led to the emergence of a new small strata of the nouveau riche, which lives in relative opulence. This small but growing group is comprised of women informal traders in the more lucrative businesses such as, dressmaking, confectioneries, hairdressing, and food. The newly rich capitalists are building new houses in Maseru's sprawling suburbs, driving posh cars, and spending time and money in leisure activities - eating out, drinking, partying and "braaiing" (barbequing). Such ostentatious enjoyment of the good life by a small minority of wealthy women should not blind us to the glaring gender inequalities in the larger society.

While rich women dine, wine and party, poor women eke out a marginal existence in the run-down neighbourhoods of Maseru. Although sharing the same geographical space, the life styles, tastes and habits of the upper class women are worlds apart from those of their poorer compatriots who live in squalor. To this extent, the informal economy has contributed to dividing and disempowering women along class lines. As Ford (2002, p. 1) put it aptly:

Just because women share sex-linked biological characteristics with one another does not mean that they embrace a single understanding of gender equality nor does it mean that they possess a group identity or group consciousness as women in a way that easily translates into political action.

The informal economy, by offering some increased incomes and prosperity, while offering others low and falling incomes, has contributed to the amplification of class divisions among women.

\subsection{Traditional Gender Stereotyping}

Notwithstanding their numerical superiority, women continue to face considerable traditional and cultural, economic and political barriers to effective participation in the informal sector and to free expression of their minds. Even though women numerically dominate the informal sector, men control the more lucrative business ventures in this resurgent sector. Paradoxically, patriarchal stereotyping, traditional representations of femininity and masculinity are being simultaneously challenged and 
reproduced in the informal sector. For example, and reflecting the difficulties of overcoming patriarchal stereotypes, women are still expected to remain in the kitchen, cook and care for their families, perform tasks designated as feminine and be submissive to men. Independent, strong and successful women entrepreneurs who defy these stereotypes are often described as: "She is a man in her own right", and stereotyped as "unwomanly". Similarly, the worst excesses of capitalism, such as crude oppression and super exploitation of workers, working long hours under unhealthy and unsafe conditions, lack of employments benefits (pension, medical aid, leave, etc.) and poor customer care, are being reproduced with immunity in the informal sector. In short, while providing livelihood to many and giving women an unprecedented opportunity for challenging traditional gender power imbalances, the informal sector is also a site for wealth accumulation, social differentiation among women and reproduction of traditional gender stereotypes.

\subsection{Implications for Feminist and Development Theory}

Liberal, post-colonial and radical feminist theories tend to portray woman as a homogenous analytical category and to depict the informal economy negatively. These dominant theories cannot adequately account for the unfolding changes and models of development in the informal sector. Not only are they gender insensitive, but they also focus only on formal economic activities, the state, visible political institutions, and high profile public projects. For example, the modernization theories of the 1960s, which have largely informed post-colonial development policy in Africa, dismisses the informal economy as the "traditional sector" which resists change and therefore an obstacle to development (Huntington, 1968). The truth is, women informal traders are not only embracing change, technology and new ways of doing business, for example, by using cell-phones and the internet to promote their businesses, but are also active agents of change. Marxists stress class conflict as the locomotive for social change, but Basotho women are not only united and divided by class, but also by age, education and religion, among others.

Similarly, the negative images of the informal sector reflected in its depiction—by officialdom, especially government bureaucrats only interested in tax collection-as a "black economy", "shadow" or "sinkhole of exploitation" are not completely justified. As we have seen, informal traders are having a positive impact on society, the economy and national development. In particular, they are contributing immensely to human and state security: by creating employment the informal economy offers alternative livelihood to potential or past criminals and rebels. Therefore discourses dismissing and denigrating the women dominated informal sector seem to have a deliberate power agenda of entrenching the statusquo, in which the unemployed poor are permanently disempowered. Also the negative connotations attached to the informal sector and traders can disadvantage and disempower them in many ways. To start with, informal traders do not get the recognition, reward and respect they deserve for the important work they are doing of enhancing human and state security. Furthermore, because of the negative stereotype, informal traders have difficulties in applying for bank loans. Even 
worse still, although they are important agents of change, informal traders are not prioritized in public policy, but are instead on the receiving end of policy. In short, the naming and labelling of informal traders in negative ways reflects an imbalance in power relations between the dominant male elite that controls the state and the subjugated poor females.

In summation, women informal traders in Lesotho are unique, and their situation is too complex to be amenable to mono-causal analysis. No doubt, the informal sector is more than just a "traditional sector" that resists development or a "sinkhole of exploitation". Instead, the sector is the major source of hope and livelihood sustenance for poor women who seek financial freedom and who wish to free themselves from being prisoners of patriarchy and/or corporate capital. In the context of continuing economic crisis, limited natural resources, local retrenchments and rising unemployment, one cannot over-emphasize the benefits to society of the informal economy. Yet, the macro-economic environment in which informal traders operate continue to impose considerable constraints on their operations, expansion and contribution to development. Without a supportive policy framework, Lesotho's "daughters will continue to bleed". The challenge is to create, through policy re-orientation, an enabling environment that promotes gender equality and unleashes the potential of the informal sector.

\subsection{Policy Options: Empowering Women through Informal Enterprising}

Since women account for over half Lesotho's population, development would be incomplete, and even inconceivable, without gender equality. Gender inequality endangers not only the health and welfare of women, but also of their families and society. Further, since the majority of economically active women are in the informal sector, society cannot develop or be democratic if these women do not have full economic and political rights. Women's economic rights are the key to unlocking Lesotho's future development: Economic "empowerment of women is the link between trade and development" (EmpowerWomen.org, 2015). As Joaquim Chissanno, the former president of Mozambique and co-chair of the International Conference on Population and Development (ICPD), stressed:

Women and girls are Africa's greatest untapped resource, and it is they, not diamonds or oil and minerals, that will be the foundation for solid, sustainable and equitable progress. ...Expanding the freedoms, the education and opportunities for women hold the key to kick-starting inclusive economic growth (NA, 2015, p. 45).

Remarkably, the 2015 African Union (AU) summit's theme was about empowering African women. Empowering women involves, as Dlamini-Zuma, the chairperson of the AU Commission declared, increasing women's representation in government, in the judiciary and other public and private institutions and their participation at the tables in peace negotiations (NA, 2015, p. 45).

First and foremost, remedial policy should identify the benefits of the informal sector, and on that basis, formulate a clear policy position on the sector. Some of the obvious benefits of the informal sector include: creating employment; providing incomes and livelihood for the poor; enhancing human security; creating wealth; contributing to national income and GDP; contributing to political stability 
and bolstering state security; supporting and subsidizing the formal sector; and entrenching the much needed entrepreneurial spirit and financial discipline. Yet, without assistance in accessing capital, technical know-how and the application of knowledge-based practices, the full potential of women informal traders will not be realized, and they may be doomed to "boondoggling", that is, producing bad goods, with bad methods and tools and making bad returns (Lipkin \& Gillis, 2000). Breaking this vicious circle of poverty demands a fundamental change in thinking about informal traders, from viewing them as a "nuisance" to acknowledging them as entrepreneurs with a potential to contribute to national development. As Dewar and Watson (1991, p. 183) point out, there should be "a careful disaggregation ... to determine exactly where the possibilities of expansion or contraction are likely to be".

In particular, a women empowering new policy framework should address the concerns and demands raised by women informal traders. It should also be aligned with the post-2015 sustainable development goals, which have superseded the Millennium Development Goals (MDGs), and with the AU 2015 theme and vision 2063. In partnership with the private sector and donors, the government could establish a fund or trust, like the Swaziland Women Empowerment Trust (SWEET), which offers credit, training and skills to its members. The informal sector could also be taxed, and thus expand and boost government revenue. Customary laws and traditional practices that discriminate against women, for example on inheritance and ownership of property, should be abolished.

To recap, optimizing the developmental potential of the informal sector requires reconciling and harmonizing, through policy, the needs of informal traders and the interests of the state as well as strengthening the synergies between the informal and formal sectors. Addressing the many demands of female informal traders involves identifying strategic entry points which facilitate certain economic activities while suppressing others, such as sex work. As they reproduce themselves on an extended scale, these nascent capitalists without capital could, as many have, graduate into formal entrepreneurs, and make greater contribution to human security, national development, and peace and stability. In a nutshell, the challenges of a gendered informal sector require a sensitive policy that treads a delicate balance between a naive celebration of this sector and its outright condemnation.

\section{Summary}

Marginalised by traditional patriarchal ideologies, the state, and the Bretton-Woods institutions, women informal traders are doing something to address the economic failures of post-independence development. In the informal economy, which is an "enclave" of an enclave economy, some women are creating wealth and prospering while others are enduring exploitation and eking out a marginal existence. Straddling tradition and modernity, the informal sector does not constitute a new mode of production, but is instead a hybrid economic system that in its operation seems closer to the African realities than the formal sector. While engendering shifts in the gender balance of power between the 
sexes, as age old values and norms give way to new ones dictated by the new economic reality, the informal economy has also created new cleavages and divisions among women.

To sum up, poor women are taking the initiative to expand their economic freedoms by engaging in informal economic activity. Women's involvement in the informal sector has not only given them access to income and contributed to national development, but has also catalysed a "quiet gender revolution", in which age old patriarchal relations are transformed as some women entrepreneurs graduate from financial dependency to autonomy. Women's new freedoms are manifested in their increasing decision making powers within the household and increased involvement in leisure activities. Yet, the informal sector has also precipitated social differentiation and divisions among women. In a word, to effectively deal with the challenges facing Lesotho, there is need for a paradigm shift from a patriarchal and formalistic bias to a comprehensive gender sensitive approach that optimizes the potential benefits of gender equality and informal sector entrepreneurship.

\section{Conclusion}

The politics of gender and development in Lesotho is implicated in unequal power relations between the sexes. The informal economy has provided women with an economic base to articulate a new politics of emancipation and gender equality. But the state and traditional patriarchal ideology continue to undermine both the emancipation of women and the flourishing of the informal economy. In spite of this, poor women continue to flock to the informal economy as it is the only vehicle for escaping from poverty, accessing income, gaining financial independence, and being empowered. The momentum of the resurgence of the informal economy has been enormous and the remarkable increasing presence of women in this economy makes them important actors in change and development. Lesotho, therefore, needs to set free a new emancipatory vision that increases "the freedoms", "education", "opportunities", and equal representation of women in positions of power as a strategy for eradicating gender inequality and poverty. In conclusion, the challenge is to develop a new emancipatory vision that transcends the parochialism of the dominant theories, and that gives a positive form to the struggle for gender equality and informal enterprising.

\section{References}

Baylis, C., \& Wright. (1993). Female Labour in the Textile and Clothing Industry of Lesotho. African Affairs, 92, 369, 577-591.

Broomley, R. (1992). The Urban Economy: Why is it Worth Discussing? World Development, 6(9/10), 1033-1039.

Bureau of Statistics. (2003). 2001 Lesotho Demographic Survey: Analytical Report. Bureau of Statistics, Ministry of Finance and Planning, Maseru.

Butler, J. (2006). Gender Trouble: Feminism and the Subversion of Identity. Routledge, London. 
Castells, M. (2000). The Rise of the Network Society: The Information Age-Economy, Society and Culture (Vol. 1). Blackwell, Oxford.

Central Intelligence of America (CIA). (2015). The World Fact Book-Lesotho. Retrieved from http://www.cia.gov/cia/publications/factbook/geos/lt.html

Couzens, T. (2003). Murder AtMorija. Random House, Johannesburg.

de Beauvoir, S. (1964). The Second Sex. Harper Collins, London.

Dewar, D., \& Watson V. (1991). Urban Planning and the Informal Economy. In E. Preston-Whyte, \& C. Rogerson (Eds.) (1991), South Africa's Informal Economy. Oxford University Press, Oxford.

Doomson-Lindsay, A. (2013). Neopatrialism and the Swazi State. Politeia, 32(3), 28-47.

EmpowerWomen.org. (2015). Economic Empowerment of Women is the Link Between Trade and Development. Retrieved from https://www.uk-mg42.mail.yahoo.com/neo/launch?.rand=bk66vb036894

Epprecht, M. (1995). Women's Conservatism and the Politics of Gender in Colonial Lesotho. Journal of African History, 36, 29-56. https://dx.doi.org/10.1017/S0021853700026967

Epprecht, M. (2000). Is This Matter of Women is Getting Bad?: Gender, Development and Politics in Colonial Lesotho. University of Natal Press, Pietmaritzburg.

Ferguson, J. (1990). The Anti-politics Machine: "Development", Depoliticization, and Bureaucratic Power in Lesotho. Cambridge University Press, Cambridge.

Ford, L. (2002). Women and Politics: The Pursuit of Equality. Houghton Mifflin, New York.

Hart, K. (1971). Informal Income and Opportunities and the Structure of Employment in Ghana. Journal of Modern African Studies, 1, 61-89. https://dx.doi.org/10.1080/00020187108707347

Huntington, S. P. (1968). Political Order in Changing Societies. London, Yale University Press.

Inglehart, R. et al. (2003). Gender, Equality and Democracy. In Inglehart (Ed.), Human Values and Social Change: Findings from the Values Survey. Brill, Leiden-Boston.

Kay, J. (2004). The Truth About Markets: Why Some Nations are Rich, But Most Remain Poor. Penguin Books, London.

Keen, S. (1996). Fire in the Belly: On Being a Man. Plaktus, London.

Kingdom of Lesotho. (1980). Third Five-Year Development Plan, 1980-1985. Government of Lesotho, Maseru.

Klay, G., \& Argbese, O. (2008). The State in Africa: Issues and Perspectives. Kraft Books, New York.

Kotelo, P. (2003). The Role of Women in the Informal Sector (Unpublished Student Project). National University of Lesotho (NUL), Development Studies Unit, Roma.

Lipkin, M., \& Gillis, A. (2000). Juiced! How To Succeed Through Spectacular Customer Service. Touch The Sky Publishing, Johannesburg.

MacGaffey, J. et al. (1991). The Real Economy of Zaire: The Contribution of Smuggling and other Unofficial Activities to National Wealth. James Currey, London. 
Makoa, F. K. (1999). Lesotho's Rural Development Policy: Objectives and Problems. Review of Southern African Studies, 3(1), 21-30. https://dx.doi.org/10.4314/rosas.v3i1.22987

Mapetla, M., \& Petlane, T. (2007). State of Good Governanance in Lesotho, 1993-2003. Insititute of Southern African Studies, National University of Lesotho, Roma.

Mueller, M. (1977). Women and Men, Power and Powerlessness in Lesotho. Signs, 3(1), 154-166. https://dx.doi.org/10.1086/493448

NA. (2015). African Union: Gender is the Agenda. New African, 548, 44-45.

Ntabheni-Bhebe. (2011). Financial Independence: What Every Women Wants. FLAME, Harare.

Nyawo, S., \& Nsibande, N. (2014). Beyond Parity: Gender in the Context of Educational Leadership. UNISWA Journal of Research, 27, 45-58.

Oyewumi, O. (1997). The Invention of Women: Making an African Sense of Western Gender Discourses. University of Minnesota Press, Minnesota.

Portes, A., \& Walton, J. (1991). Labour, Class and the International System. Academic Press, New York.

Preston-Whyte, E., \& Rogerson, C. (Eds.). (1991). South Africa's Informal Economy. Oxford University Press, Oxford.

Sacks, K. (1982). An Overview of Women in Power in Africa. In J. O’Barr (Ed.), Perceptions on Power: Women in Africa, Asia and Latin America. Dules University Press, New York.

Sandbrook, R. (2000). Closing the Circle: Democratization and Development in Africa. Zed Books, London.

Shea, Q. (2003). The Contribution of the Informal Sector to the Development of the Poor: The Case of Hawking in the Maseru Town (Unpublished Student Project). National University of Lesotho, (NUL), Development Studies Unit.

Sow, F. (1997). Gender Relations in the African Environment. In A. M. Imam, \& F. Sow (Eds.), Endegedering African Social Sciences (pp. 251-270). CODESRIA, Dakar.

Swazi Observer. (2016). Women's Rights key to Africa’s Future. Swazi Observer, 11 March, Mbabane.

Thakalekoala, T. (2003). A Badly-burnt Body Of A Young Man Found At Borokhoaneng. The Survivor, Maseru, 3 August.

Thakalekoala, T. (2003). Journalists Come Under Fire as MCC Clashes With Maseru Vendors. The Survivor, Maseru, 3 August.

Women in Informal Employment Globalizing and Organizing (WIEGO). (2015). Retrieved from http://www.wiego.org.m-ain/fact.shtml

World Bank. (1986). World Development Report. Washington DC.

Worsley, P. (1984). The Three Worlds: Culture and Development. Weidenfield, London. 


\section{Note}

Note 1. Economy of affections means trade relations are tempered by love, that is, unlike under strict capitalist trade where you get only what you pay for, buyers are often given a little extra portion, partly to lure them into becoming regular customers. In this economy, kinsmen do not always exchange their labour for a wage; sometimes they just do some jobs for free, to help out of love. 